\title{
Educação e trabalho nas Considerações sobre o governo da Polônia de Jean-Jacques Rousseau
}

\author{
Suzana Guerra Albornoz \\ Universidade de Santa Cruz do Sul
}

Em "Considerações sobre o governo da Polônia", de Jean-Jacques Rousseau, o programa apresentado mostra aspectos de dimensão utópica com toques de idealização patriótica e saudosismo conservador. Este artigo ressalta detalhes dos capítulos daquela obra referentes à organização econômica, à educação e ao trabalho na administração pública.

Palavras-chave: Rousseau, Polônia, Patriotismo, Cultura nacional, Riqueza agrícola, Simplicidade da ordem, Distribuição do trabalho, Probidade administrativa, Crítica ao dinheiro, Educação.

Education and work in Considerations on the government of Poland of Jean-Jacques Rousseau

In "Considerations on the government of Poland", by Jean-Jacques Rousseau, the presented program shows aspects of utopian dimension, with touches of patriotic idealisation and conservative idealism. This article points to details of those chapters of these work which reffers to economic organisation, education and to public administration.

Keywords: Rousseau, Poland, Patriotism, National culture, Agrar richness, Order simplicity, Labour distribution, Administrative honesty, Critics of money, Education.

\section{Introdução}

Z ste é o terceiro de uma série reunida sob o título comum de Trabalho e utopia na Cmodernidade - de Thomas More a Paul Lafargue. Nesta série de escritos, pretendo fazer uma visita ao detalhe de alguns textos exemplares de autores modernos com dimensão utópica, desde o século XVI até o XIX. O primeiro desses textos versou sobre a Utopia de Thomas More; o segundo abordou A Cidade do Sol, de Tommaso Campanella. Apenas um grande autor foi destacado como exemplar da literatura utópica em cada um dos primeiros três séculos modernos e estão previstos somente dois escolhidos para dar-nos testemunho da múltipla e rica utopia no século XIX: Charles Fourier e Paul Lafargue.

Ao que o longo período de quatro séculos pareceria indicar de amplitude, a seleção violenta de poucos textos e a lente sobre o detalhe fazem contrapeso. Trata-se aqui apenas destaques de fragmentos, reconsiderados como se com lente de aumento para serem vistos mais uma vez e, assim, adquirirem para os leitores mais uma nuance de significado na continuação de tantas outras leituras. Como o título acima indica, este terceiro texto atém-se a uma das obras de Jean-Jacques Rousseau sobre a qual pode-se supor pairar o "espírito da utopia”, ou seja, as Considerações sobre o governo da Polônia.

Jean-Jacques Rousseau (1712-1778) é reconhecidamente um dos nomes mais importantes da história das idéias e das letras européias do século XVIII e de toda a modernidade. Sua relação com o Iluminismo francês, biográfica e filosófica, foi paradoxal e 
sui generis, contudo, inegável. Cidadão de Genebra, interlocutor e provocador de Voltaire em Paris, hóspede de Hume na Inglaterra, pomo de discórdia de grandes polêmicas, Rousseau transformou-se em pólo desafiador à lucidez do processo de valorização da razão. Pode-se reconhecer em Rousseau ao mesmo tempo um crítico da tradição filosófica e pedagógica e também um crítico das novas Luzes com sua idealização da razão, sendo que, nesse sentido, Rousseau fez avançar o Iluminismo por sua própria crítica.

O conhecimento sobre o homem e o desenvolvimento das ciências humanas, que então assim nem se chamavam, não permaneceram os mesmos depois da obra irregular desse grande escritor solitário. A filosofia política, a partir de suas idéias, sofreu uma guinada radical que abriria caminho através do socialismo, de Marx e o marxismo, para os estudos críticos da sociedade, as ciências sociais, os movimentos emancipatórios, dando origem a uma série de produções práticas e teóricas que até hoje não terminaram de influenciar e inspirar transformações da vida social. Especialmente a educação e a filosofia da educação, a partir do Emílio, começam vida nova por uma nova forma de ligar formação e aprendizagem com a própria vida, implicando em uma nova atitude, ao mesmo tempo, ante a formação moral religiosa tradicional e a instrução moderna, vista como educação da e pela razão.

É desnecessário, portanto, justificar a referência a Rousseau quando se trata de pesquisar idéias no século XVIII, sobretudo quando os temas são a educação e as relações humanas do plano do trabalho, onde se instala a desigualdade social, educação e desigualdade, sendo todos esses temas centrais da reflexão do filósofo. Todavia, é preciso tentar responder a pergunta sobre as razões de incluir Jean-Jacques Rousseau numa pesquisa sobre as utopias, ou seja, o domínio da produção de sonhos na modernidade. Por que incluir Jean-Jacques ao pesquisar o acervo das utopias modernas? Ao fazê-lo autorizam-nos os especialistas na história das utopias modernas; ainda assim, convém verificar suas razões expressas.

Jean-Christian Petitfils (1977) inclui Rousseau em seu livro sobre os socialismos utópicos, no qual classifica a obra do filósofo entre as "utopias retrógradas"; e naquele capítulo o inclui pela característica de condenação do Estado e das estruturas sociais de sua época, tais como a propriedade privada, à qual é atribuída a miséria social existente, "reflexo degradado de um estado anterior de pura perfeição".

Petitfils refere a opinião (exagerada) de que Rousseau seria o fundador do comunismo moderno e lembra que foram numerosos os escritores revolucionários e utopistas do século XIX a copiarem de Rousseau seus argumentos contra a sociedade, tomando como modelo e inspiração o Discurso sobre a origem e o fundamento da desigualdade entre os homens(1754):

a inocência e a bondade primitivas do homem, o papel corruptor e nefasto da propriedade privada, causa de guerras, crimes e misérias, o papel dos fatores econômicos na formação de desigualdades, a aspiração a uma sociedade perfeitamente igualitária (Petitfils, 1977, p. 28).

Pela grande influência exercida sobre seu tempo e sobre as gerações seguintes pelo filósofo de Genebra, influência paradoxal para um homem não muito bem compreendido e aceito entre seus contemporâneos - que conviveu tanto com a fama e a grande repercussão de seus escritos quanto com a crítica exacerbada, a perseguição e o ridículo -, a inclusão do nome de Rousseau é obrigatório num estudo sobre o século XVIII, não só quando o objeto é a filosofia política e as teorias contratualistas, mas também quando se busca entender a história das utopias, abundantes no século das Luzes, ao lado do movimento próprio da filosofia e da ciência, ou seja, das produções mais racionais do espírito humano.

A influência de Rousseau sobre as ciências humanas aparece como paradoxal quando lembramos sua crítica da sociedade e da civilização - ou seja, das ciências, técnicas, artes e do 
progresso em geral, naquele tempo afirmação política da burguesia e da revolução industrial, quando o progresso se transforma em algo próximo de substituto para o sagrado e a religião.

O paradoxo de Rousseau tem por limite, de um lado, a famosa crítica de Voltaire, de que ninguém como Jean-Jacques "teria usado tanto o espírito para tentar transformar os homens em animais"; de outro, a sua crítica da tradição e a aposta na atitude criadora, que assume diante da perfectibilidade do homem - atitude evidente em suas obras de reforma moral como Júlia ou a nova Heloísa - ou de reforma dos princípios educativos como O Emílio, reflexão que iria fertilizar a produção de toda a pedagogia moderna, espécie de ápice da afirmação do artificialismo instalado no âmbito mais íntimo das relações humanas, entre pais e mães e filhos.

Petitfils observa que os projetos reformadores - tanto o Projeto para a Córsega, como as Considerações sobre o governo da Polônia - não apresentam o aspecto subversivo que nos permitiria classificá-los entre as utopias socialistas. Nesses projetos políticos e sociais bastante pragmáticos são abandonados aspectos mais radicais da crítica da propriedade individual presentes em textos anteriores do filósofo, o qual passava a recomendar uma reforma onde se consagraria o direito de propriedade, embora manifestando o desejo de vê-lo contido em estreitos limites. Sob esse aspecto, Rousseau acompanha o ideal dos jacobinos, que sonhavam organizar a sociedade como uma multidão de pequenos proprietários de costumes simples, próximos da natureza, que assim não precisariam senão de um mínimo de bens para subsistência.

Deixando as doces margens da utopia, Jean-Jacques abordou o realismo político para tornar-se assim o visionário fulgurante da democracia futura, ao mesmo tempo que se tornava também o apóstolo inquietante dos totalitarismos modernos (Petitfils, 1977, p. 29).

Por outro lado, o texto das Considerações sobre o governo da Polônia só mediatamente pode ser situado entre as utopias, pois ali não se trata de um país imaginário, existente em nenhum lugar, como os encontrados nas aventuras de exploradores lendários que fazem o gênero das utopias e que, na verdade, veiculam e mascaram a crítica e a sugestão de reforma social. Rousseau não escreveu uma "viagem imaginária", como era o caso da Utopia de Sir Thomas More. No entanto, são inúmeros os leitores e observadores que acentuam o lado utópico dos textos rousseaunianos, por assim dizer, o seu aspecto de utopia, e o consideram como "um sonhador em política" (Baczko, 1978, p. 67), o que é compreensível também quando no título da última obra - espécie de conclusão e revisão de todas as obras, o pensador se apresentava a si mesmo como "um passeante solitário envolto em devaneios".

\section{As Considerações sobre o governo da Polônia e sobre sua projetada reforma}

Nesse texto difícil de ser classificado, que os historiadores de utopias hesitam em considerar como tal, encontramos a voz expressiva do mesmo espírito crítico sobre o mundo desigualitário europeu que então dominava o mundo - ainda no ancien régime, já com influência da nova classe dominante, a burguesa -, manifestando-se sobre os aspectos da organização social e política que um bom governo deveria prever, portanto, também e especialmente, sobre o sistema econômico. 


\section{A formação da alma nacional pela educação}

O capítulo sobre educação, hoje, não conseguiria ser apresentado como utópico, talvez justamente por ter sido grande a influência de Rousseau sobre o campo da educação nos últimos séculos, o que nos impede de perceber exatamente o aspecto inovador de suas propostas para a sua época. A organização pública da educação é ali apresentada como de importância central, sobretudo na formação do que chama de "alma nacional". Rousseau considera a educação o meio de construção da nação e a grande tarefa nacionalista. É pela educação que seria possível criar a identidade e a força do país.

Este é o artigo importante. A educação é que deve dar às almas a forma nacional, e dirigir suas opiniões e seus gostos de tal modo que sejam patriotas por inclinação, por paixão, por necessidade. Uma criança ao abrir os olhos deve ver a pátria e até sua morte deve ver mais do que ela (Rousseau, 1990, p. 177).

Surpreende-nos a manifestação da paixão patriótica projetada sobre o pano de fundo do tempo das Luzes da razão, cuja face cosmopolita permanece hoje mais brilhante e quase faz esquecer a nacionalista:

Todo verdadeiro republicano sugou com o leite de sua mãe o amor de sua pátria, isto é, das leis e da liberdade. Este amor faz toda a sua existência; ele nada vê além da pátria, vive somente para ela; quando está só, ele é nada: quando não tem mais pátria, não mais existe; e se não está morto, está ainda pior (Rousseau, 1990, p. 177-178).

Chama a atenção que no filósofo esclarecido, idealizador do Estado popular, o patriotismo, tão acentuado neste projeto para a Polônia, seja dado como vida do indivíduo. Após o século XX, quando se vê com certa distância o doloroso momento do nacionalismo europeu e quando o cosmopolitismo parece mais consoante às necessidades de paz e de convivência desta época em que as tecnologias condicionam à mundialização, o entusiasmo patriótico rousseauniano causa espanto:

A educação nacional pertence apenas aos homens livres; somente eles possuem uma existência comum e são verdadeiramente ligados pela Lei. Um francês, um inglês, um espanhol, um italiano, um russo, são todos mais ou menos o mesmo homem; este sai do colégio já todo marcado pelo desregramento, quer dizer, pela servidão. Aos vinte anos, um polonês não deve ser um outro homem; deve ser um polonês (Rousseau, 1990, p. 178).

O primeiro objetivo da educação aparece nesse texto de Rousseau como sendo a identificação do homem particular com o seu povo, a identificação do indivíduo com o cidadão e a impregnação do indivíduo com a identidade nacional. É esse processo de identificação com a pátria que constituirá o lastro da disciplina pessoal, que por sua vez garantirá a verdadeira liberdade:

(...) que, ao aprender a ler, leia sobre as coisas de seu país, que aos dez anos conheça todas as suas produções, aos doze, todas as províncias, todos os caminhos, todas as cidades, e aos quinze saiba toda a sua história, aos dezesseis, todas as suas leis; que não haja em toda a Polônia nenhuma bela ação, nenhum homem ilustre de que ele não tenha cheios a memória e o coração, e sobre os quais não possa responder na hora (Rousseau, 1990, p. 178).

A boa educação de alguém será, pois, avaliada pelo grau de sua inserção na cultura geral, entendida como cultura popular. Não se esqueça esse traço nacional, nacionalista da educação sonhada por Rousseau, que se expressa a propósito da reforma da constituição 
polonesa. Com isso, o escritor criava polêmica com a tendência histórica daquele tempo na Polônia, que era de importar professores estrangeiros e educar em moldes ocidentais, ou melhor, franceses.

A lei deve regular a matéria, a ordem e a forma de seus estudos. Não devem ter por professores senão poloneses, todos casados, se possível, todos notáveis por seus costumes, por sua probidade, por seu bom senso, por suas luzes, e todos destinados a empregos... (Rousseau, 1990, p. 178).

A educação popular, pensada como nacionalizante (ou socializante), que tem por primeira meta inserir profundamente o indivíduo em sua cultura, nas tradições e nas leis de seu povo, tem em vista, pois, sua inserção no mundo da economia e do trabalho, que dá corpo à vida social; e é aqui onde reencontramos a pergunta principal desta pesquisa, pois tais indivíduos/cidadãos serão "todos destinados a empregos":

não mais importantes nem mais honrosos, porque isto não é possível, mas menos penosos e mais brilhantes, uma vez que depois de certo número de anos, os realizarão bem (Rousseau, 1990, p. 178).

A educação nacional estará de olho na formação do cidadão trabalhador produtivo para os novos tempos que se iniciam, onde o "antigo regime" de dominação da nobreza associada à produção rural está em em vias de dar lugar à sociedade industrial, de dominação plebéia. A frase diz mais, quando termina com uma recomendação sobre o trabalho do educador: "Evitai sobretudo de tornar profissão o estado de pedagogo" (Rousseau, 1990, p. 178).

Nesse sentido, nosso tempo se encontra muito afastado de Rousseau; para os "profissionais da educação", organizados em associações de classe laboral e sindicatos, há de parecer absurdo, pelo menos estranho que se questione o caráter profissional do trabalho pedagógico. Por outro lado, Rousseau questiona as diferenças de tratamento dadas às diversas categorias sociais dentro da escola, conforme a riqueza ou a modéstia econômica, diferenças que em seu tempo atingiam mesmo segmentos da nobreza:

Todos sendo iguais pela constituição do Estado devem ser educados juntos e da mesma maneira, e se não se pode estabelecer uma educação pública totalmente gratuita, é necessário pelo menos colocá-la a um preço que os pobres possam pagar (Rousseau, 1990, p. 179).

Partindo da preocupação igualitária, o filósofo pensa o detalhe concreto, chegando à idéia de vagas gratuitas pelo sistema de bolsas de estudo, expediente ainda hoje utilizado pelos sistemas de educação que não conseguiram equacionar satisfatoriamente o ideal moderno de igualdade na educação com a ação do Estado.

Não seria possível criar em cada colégio um certo número de vagas puramente gratuitas, quer dizer, às custas do Estado, que na França se chama de bolsas? Estas vagas, dadas aos filhos dos nobres pobres que mereçam consideração da pátria, não como esmola, mas como recompensa por bons serviços prestados à pátria por seus pais, a este título se tornariam homens de honra, o que poderia produzir uma dupla vantagem que não se deve negligenciar (Rousseau, 1990, p. 179).

Pode soar hoje como obviedade, contudo, em seu tempo, quando predominavam as posições intelectualistas quanto à educação dos jovens e das crianças, apresentava um caráter utópico a reivindicação de um lugar importante para a educação física na educação infantil: 
Em todos os colégios é preciso instalar um ginásio ou lugar de exercícios corporais, para as crianças. Este aspecto tão negligenciado é a meu ver a parte mais importante da educação, não somente para formar temperamentos robustos e sadios, mas ainda mais para o objeto moral, que é negligenciado, ou que se atende apenas por uma série de preceitos pedantes e vãos, que são tantas palavras perdidas (Rousseau, 1990, p. 179).

A educação física é associada ao aspecto da orientação rousseauniana que impregnou profundamente a pedagogia nos dois últimos séculos, ou seja, a orientação na direção do que se pode chamar de "pedagogia negativa", a não interferência entendida como respeito à tendência espontânea, auto-orientada, natural da criança.

Jamais repetirei o bastante que a boa educação deve ser negativa. Impedi de nascerem os vícios, tereis feito o suficiente pela virtude. O meio é de última facilidade na boa educação pública. Trata-se de manter as crianças sempre treinadas, não em tediosos estudos onde nada entendem e vão odiar só pelo fato de por eles serem obrigadas a ficar paradas; mas por exercícios que lhes agradem, satisfazendo a necessidade que seu corpo tem de, ao crescer, agitar-se... (Rousseau, 1990, pp. 179-180).

Rousseau manifesta-se várias vezes no texto estudado por uma maior valorização da educação física e esta é compreendida como submissa à meta maior da educação para o patriotismo e o senso nacional, confirmando-se uma posição que no século XVIII deveria soar revolucionária:

Sua instrução pode ser doméstica e particular, mas seus jogos devem sempre ser públicos e comuns a todos; porque não se trata aqui somente de ocupá-los, formar-lhes uma constituição robusta, torná-los ágeis e bem-feitos de corpo; mas de acostumá-los desde cedo à regra, à igualdade, à fraternidade, às concorrências, a viver sob os olhos de seus concidadãos e a desejar a aprovação pública (Rousseau, 1990, p. 180).

O cuidado com a educação corporal e a afirmação do seu valor para a educação da solidariedade e da cidadania pode ser interpretado como expressão do humanismo moderno, que emerge na renascença e cuja inspiração se encontra na antigüidade greco-romana, separando-se nisso dos séculos medievais, nos quais a fonte mais fortemente presente se associava no cristianismo à herança cultural de origem bíblica. Aí está expresso e claro que na educação física não se trata apenas da saúde do corpo, mas também de outros aspectos de ordem social ou moral, que pela educação do corpo podem ser atingidos. Por outro lado, essa crítica à modernidade coloca Rousseau entre os pensadores que olham para trás, para a origem, que na origem buscam a inspiração, tanto para a crítica dos seus contemporâneos como para as recomendações de mudança - logo, a rigor, "retrógrados", assim parecendo fazer juz à classificação que lhe foi dada por Petitfils.

(...) Estas idéias mal desenvolvidas mostram de longe os caminhos ignorados pelos modernos pelos quais os antigos levavam os homens àquele vigor de alma, àquele zelo patriótico, a esta estima pelas qualidades verdadeiramente pessoais, sem cuidado pelo que é estranho ao homem, [qualidades] que não encontramos entre nós mas cujos germes nos corações de todos os homens esperam apenas, para fermentar, serem postos em ação por meio de instituições convenientes (Rousseau, 1990, p. 180).

As novas situações modernas, que incluem um novo reconhecimento do indivíduo e mesmo o individualismo como regra, são alvo de crítica contundente e de expressões ácidas: "máximas corrompidas", "instituições desgastadas", "filosofia egoísta"... O pensador se confronta com a modernidade em nome de algo que já estaria antes dela:

Dirigi neste espírito a educação, os usos, os costumes, os hábitos dos poloneses, e desenvolvereis neles este germe que ainda não foi arruinado pelas máximas corrompidas, 
pelas instituições desgastadas, por uma filosofia egoísta que prega aquilo que mata (Rousseau, 1990, p. 181).

Ou seja, Rousseau aconselha os governantes poloneses a dirigir a educação pelo espírito do humanismo nacionalista, desgastado pelas instituições no século que, se apresentava sua face das Luzes, começava a sofrer as pressões anti-humanistas da revolução industrial.

\section{A crítica ao dinheiro}

Embora o capítulo das Considerações sobre a educação comece por afirmar ser esse o ponto importante do projeto - e é interessante considerá-lo assim, ainda mais pela consciência que hoje se tem do quanto a visão de Rousseau teve influência sobre o campo da pedagogia na época contemporânea -, o capítulo sobre o sistema econômico promete também respostas à nossa pesquisa do exercício utópico sobre a questão do trabalho e da sugestão provocadora do novo - do possível que ainda-não-é, na linguagem de Ernst Bloch, o filósofo da utopia.

Rousseau começa por lembrar a questão prévia, o ponto de partida dos objetivos do governo: "A escolha do sistema econômico que a Polônia deve adotar depende do objetivo que ela se propõe ao corrigir sua constituição" (Rousseau, 1990, p. 218).

A seguir, dando resposta à pergunta feita a si mesmo, de modo retórico, lembra a alternativa que estava posta aos poloneses: a opção pelo modelo de desenvolvimento europeu ocidental e moderno, que se afirmava no século das Luzes, ou a opção pelo outro modelo, inspirado em recursos culturais e tradições da Europa Oriental, o que hoje poderia ser dito como "eslavófilo", real ainda, por exemplo, nos conflitos políticos da atualidade ucraniana.

Se quiserdes apenas tornar-vos barulhentos, brilhantes, duvidosos, e influenciar os outros povos da Europa, tendes o seu exemplo, aplicai-vos a imitá-los. Cultivai as ciências, as artes, o comércio, a indústria, organizai tropas, fortificações, academias e, sobretudo, um bom sistema de finanças que faça bem circular o dinheiro, que assim o multiplique, que vos providencie muito dinheiro; trabalhai para torná-lo muito necessário, afim de manter o povo numa grande dependência e, por isto, fomentai o luxo material e o luxo do espírito, que lhe é inseparável (Rousseau, 1990, p. 218).

À luz dessa alternativa do modelo de desenvolvimento sócio-político e cultural burguês que se afirmava na época - com insinuações a outra possibilidade de desenvolvimento não muito bem definida, que se lhe opunha -, pode-se reconhecer nas Considerações de Rousseau o seu caráter de utopia, embora possivelmente Petitfils tenha razão ao considerá-la uma "utopia retrógrada". Também é evidente o acento moralista, voltado para a formação moral do povo e, nesse sentido, preocupado com a educação, da qual o filósofo faz depender o sistema econômico.

Desta maneira formareis um povo intrigante, ardente, ávido, ambicioso, servil e patife como os outros, sempre sem nenhum meio entre os dois extremos da miséria ou da opulência, da licença ou da escravidão: mas sereis contados entre as grandes potências da Europa, entrareis em todos os sistemas políticos, vossa aliança será buscada em todas as negociações, sereis ligados por tratados: não haverá uma guerra na Europa em que não tenhais a honra de estar metidos... (Rousseau, 1990, p. 219).

A crítica ao modo de vida ocidental moderno aí não é realizada a partir da análise das relações de produção, como o faria depois Karl Marx (com notáveis consequências para a compreensão do mundo nos séculos XIX e XX), mas já se nota no discurso de Rousseau a 
aguda percepção da relação entre aspectos da concretude econômica e os traços de caráter moral que a ela estão associados, enquanto aponta associações desses fenômenos, digamos, dos planos infra e superestruturais, com os resultados políticos nas relações internacionais européias.

Mas se por acaso preferirdes formar uma nação livre, pacífica e sábia, que não tenha nem medo nem necessidade de ninguém, que seja suficiente a si mesma e seja feliz; então é preciso adotar um método inteiramente diferente, manter, reestabelecer entre vós os costumes simples, os gostos sadios, um espírito guerreiro sem ambição, formar almas corajosas e desinteressadas; aplicar vossos povos à agricultura e às artes necessárias à vida, tornar o dinheiro desprezível e, se possível, inútil, procurar, encontrar, para operar grandes coisas, recursos mais poderosos e mais seguros (Rousseau, 1990, p. 219).

"Tornar o dinheiro desprezível" e "restabelecer costumes simples", ou seja, voltar a formas singelas de vida, de uma maneira romântica, indica para a superação do modo de valoração burguesa e de interação econômica que se afirmava na época, naqueles tempos da revolução industrial e do desenvolvimento capitalista na Europa. Todavia, ao mesmo tempo pensador iluminista e crítico do iluminismo, Rousseau sabe qual a moda que predomina no centro do universo sociocultural e político de onde fala e aconselha o governo da Polônia:

Convenho que, seguindo este caminho, não enchereis as gazetas com o ruído de vossas festas, negociações, explorações, os filósofos não vos incensarão, os poetas não vos cantarão, e na Europa se falará pouco de vós: talvez mesmo afetarão desprezar-vos (Rousseau, 1990, p. 219).

Esse é o paradoxo da posição do escritor que a composição de um texto com Considerações sobre o governo da Polônia demonstra: adepto da reforma planejada e refletida da sociedade, portanto, homem inteiramente partícipe da pretensão principal de seu tempo, ao mesmo tempo, crítico das modas burguesas que então se impõem; sua esperança é que a inspiração nos valores populares da Polônia dêem a esse país as sonhadas harmonia e força para afirmar sua independência diante dos seus tradicionais invasores:

mas vivereis na verdadeira abundância, na justiça e na liberdade; não vos importunarão com querelas, sereis temidos embora sem que se deixe transparecer, e vos respondo que nem os russos nem outros virão tentar mandar em vossa casa ou, se por sua desgraça vierem, logo terão pressa em de lá sair (Rousseau, 1990, p. 219).

São duas as possibilidades para pautar uma reorganização de um governo, de um país: primeira, a do desenvolvimento segundo os cânones mais comuns da época, através das construções em diversos níveis da realidade e dentro das grandes diferenças de situações sociais e econômicas, quando pela integração nas nações em busca do sucesso material, do prestígio e do poder, os poloneses se tornariam mais um povo "barulhento, brilhante, duvidoso"; e, segunda, a da autonomia inspirada por tradições populares de austeridade e solidariedade não-burguesas, de certo modo passadistas, sem dúvida utópicas. Segundo Rousseau, não seria próprio tentar conciliar ambas possibilidades:

Sobretudo não tenteis combinar estes dois projetos; eles são demasiado contraditórios, e desejar andar pelos dois, por uma marcha composta, é querer faltar aos dois. Escolhei pois, e se preferirdes o primeiro partido, aqui cessai de ler-me; porque, de tudo o que me resta propor, tudo se liga com o segundo (Rousseau, 1990, p. 219).

O desenvolvimento dependente prometeria a riqueza, mas não poderia atender aos reclamos de progresso real que exige a autonomia do país para a organização da justiça, quer 
dizer, a liberdade com boa distribuição dos bens, ao que o filósofo vai chamar de prosperidade, distingüindo-a da riqueza.

Sem dúvida há excelentes vistas econômicas nos documentos que me foram entregues. $\mathrm{O}$ defeito que percebo é de serem mais favoráveis à riqueza do que à prosperidade. Quando se trata de novos estabelecimentos, não se pode contentar de olhar seu efeito imediato; ainda é preciso prever bem as conseqüências a longo prazo mas necessárias (Rousseau, 1990, p. 220).

Rousseau reconhece que em toda a Europa o sistema estabelecido é o de tudo ser feito pela intermediação do dinheiro, mas ante esse fato inegável, demonstrando seu distanciamento crítico, o escritor filósofo e utopista pergunta:

Mas este sistema é bom em si mesmo e realiza bem o seu objetivo? (...) É seguro que o dinheiro seja o motor de um bom governo? Os sistemas de finanças são modernos. Mas daí não vejo sair nada de bom nem de grande. Os governos antigos não conheciam sequer a palavra finança, e o que faziam com os homens era prodigioso. $\mathrm{O}$ dinheiro é no máximo o suplemento dos homens, e o suplemento jamais terá o valor da coisa mesma (Rousseau, 1990, p. 220).

Quão inusitada soaria essa peroração se feita hoje ante nossos governos da atualidade! Mesmo a lembrança de que os povos pobres podem vencer os ricos na guerra já estava ali presente, esse fato que parece confirmado com as guerras regionais do século XX, mas que ainda não terminaram por convencer os dirigentes bélicos do XXI.

Poloneses, deixai-me todo este dinheiro para os outros, ou contentai-vos daquele que será bom que vos dêem, uma vez que eles têm mais necessidade de vosso trigo do que vós de seu ouro. Vale mais, creiam-me, viver na abundância que na opulência; sede melhor que pecuniariamente fortes, sede ricos (Rousseau, 1990, p. 220).

Interessante é salientar aqui a diferença registrada entre os conceitos de "ricos" e "pecuniariamente fortes", o que revela e dá a pensar sobre a orientação filosófica e moral do escritor.

Cultivai bem vossos campos, sem vos preocupardes com o resto, logo colhereis ouro e mais do que o necessário para vos abastecerdes do óleo e do vinho que vos faltam, pois na Polônia de quase tudo há abundância ou pode haver abundância. Para vos manterdes felizes e livres, o que é preciso são cabeças, corações, e braços: é isto que faz a força de um Estado e a prosperidade de um povo (Rousseau, 1990, p. 220).

Mais que uma valorização do trabalho, no discurso rousseauniano está posta claramente uma crítica do dinheiro e da moeda, crítica do ponto de vista da moral e de uma concepção de vida humana onde a análise dos fatos econômicos reais não se separa da avaliação ética:

Buscai por todo lado, em todo país, em todo governo e por toda terra. Não encontrareis um grande mal em moral e em política onde o dinheiro não se tenha mesclado (Rousseau, 1990, p. 222).

Como se vê, para o pensador de Genebra, o dinheiro, a ambição de riqueza e a corrupção ameaçam ao mesmo tempo a moral e a política. A moral se vê atingida enquanto os bons costumes se conservam melhor dentro da modéstia e da severidade material; a política, porque suas finalidades mais nobres, relativas ao bem comum, à grandeza da nação, à felicidade geral do povo, são subvertidas pelo objetivo da acumulação. 
Se me disserem que eu quero fazer da Polônia um povo de capuchinhos, responderei primeiro que este é um argumento à francesa, e que brincar não é raciocinar. Responderei ainda que não se deve aplicar minhas máximas além de minhas intenções e da razão; que meu intuito não é suprimir a circulação das espécies, mas somente torná-la mais lenta, e provar sobretudo quanto importa que um bom sistema econômico não seja um sistema de finança e dinheiro (Rousseau, 1990, p. 223).

Com esse discurso, Rousseau chama a atenção do seu leitor privilegiado que não se há de confundir riqueza financeira com prosperidade econômica. Não se trata de enriquecer os produtores, mas de produzir o que o conjunto do país necessita:

Favorecei a agricultura e as artes úteis, não enriquecendo os cultivadores, o que não seria mais que excitá-los a deixar seu estado, mas tornando-o honroso e agradável. Estabelecei as manufaturas de primeira necessidade; multiplicai sem cessar vossos trigais e vossos homens, sem vos preocupar com o resto (Rousseau, 1990, p. 224).

Uma certa tendência anti-estrangeira, de novo, não se esconde; Rousseau recomenda olhar primeiramente para a situação interna do povo no país e não se pautar o governo da Polônia pelo comércio internacional:

O efeito infalível e natural de um governo livre e justo é a população. Quanto mais aperfeiçoardes vosso governo, mais multiplicareis vosso povo, sem mesmo sequer pensar nisso. Não tereis nem mendigos nem milionários. $\mathrm{O}$ luxo e a indigência desaparecerão juntos insensivelmente, e os cidadãos, curados dos gostos frívolos que dá a opulência, e dos vícios ligados à miséria, dedicarão seus cuidados e sua glória a bem servir a pátria e acharão sua felicidade nos seus deveres (Rousseau, 1990, p. 225).

\section{O trabalho na administração pública}

Tanto no capítulo sobre a educação, como no que trata do sistema econômico, Rousseau na realidade aborda apenas de passagem a questão do trabalho; o tema, contudo, reaparece no capítulo 10 das Considerações, que trata da administração pública. É das poucas ocasiões na obra em que, a propósito da administração do Estado e da função pública, o autor faz recomendações a respeito da atividade profissional. Tais recomendações são antes de tudo dirigidas para a administração da justiça, mas tomam uma dimensão mais ampla ao percebermos que o pensador se refere aos costumes e à cultura dos antigos, que lhe servem como modelos:

Os dois estados de homem de espada e homem de toga eram desconhecidos dos antigos. Os cidadãos não eram por profissão nem soldados, nem juízes, nem sacerdotes; eles eram tudo por dever... (Rousseau, 1990, p. 215).

Profissionalizar uma atividade aparece-lhe como um processo de aviltamento, de diminuição de sua motivação patriótica, portanto, de desvirtuamento da função pública.

A função de juiz (...) deve ser um estado passageiro de provas, no qual a nação possa apreciar o mérito e a probidade de um cidadão, para elevá-lo a seguir aos cargos mais eminentes para os quais é considerado capaz (Rousseau, 1990, p. 215).

Não sendo profissão, o cargo público, sobretudo no exercício da justiça, também é um formador da probidade do cidadão. 
Esta maneira de considerar-se a si mesmos só pode tornar os juízes muito atentos para se proteger de toda reprovação e dar-lhes geralmente toda a atenção e toda a integridade que seu cargo exige (Rousseau, 1990, p. 215).

Sensato é administrar bem a justiça com poucos juízes e poucas leis, claras e simples, deixando aos primeiros o poder de interpretar e suplementar as leis:

É preciso fazer três códigos: um político, o outro civil e o outro penal. Todos três claros, curtos e precisos, tanto quanto possível. Estes códigos serão ensinados não somente nas universidades, mas em todos os colégios, e não se tem necessidade de outro corpo legal (Rousseau, 1990, p. 216).

A justiça dá conteúdo à atividade na função pública e também repercute no sistema de ensino. Por outro lado, na educação moral, no cultivo da honestidade e o ensino da virtude está a garantia e o fundamento da justiça e do direito.

Fazei-os somente honestos e virtuosos e vos respondo que saberão de direito o suficiente (Rousseau, 1990, p. 216).

Mais uma vez se manifesta a crítica da profissionalização da atividade na função pública, e isso se aplica não só aos juízes, mas também aos advogados:

O que disse dos juízes deve estender-se por ainda mais razão aos advogados. Este estado tão respeitável em si mesmo se degrada e avilta logo que se torna uma profissão (Rousseau, 1990, pp. 216-217).

Isso não significa que se deixe o âmbito da lei à deriva e entregue à falta de seriedade; ao contrário, ele é considerado obrigação de todos, de todo e de cada cidadão, porque a rigor a aplicação da lei só se realiza quando cada cidadão conhece a lei e, por isso, pode respeitá-la e agir dentro de suas prescrições:

Mas é preciso que todos os cidadãos e, sobretudo, os homens públicos sejam instruídos pelas leis positivas de seu país e as regras particulares sobre as quais são governados (Rousseau, 1990, p. 216).

O pensador considera o trabalho produtivo (no capítulo sobre o sistema econômico) e o trabalho no serviço do Estado (no capítulo sobre a administração pública). Para o primeiro, bem como para o segundo, reivindica espaço para a educação do cidadão, educação moral e política, popular e nacional, que situa além da profissionalização.

\section{Comentário}

Em nosso primeiro texto desta série, quando abordávamos a Utopia de Thomas More, já alertávamos para a ambigüidade, mesmo a duplicidade de sentido daquele relato, que, ao mesmo tempo em que inaugurava o gênero literário chamado de "utopia", versando sobre viagens a ilhas imaginárias que passavam a constituir modelos para a necessária reforma do velho mundo, era também um modo mascarado, irônico, de crítica à sociedade real da época - naquele caso específico de More, uma sutil crítica a Inglaterra de Henrique VIII.

Quando da ocasião do segundo texto da série, sobre Tommaso Campanella, espero também ter deixado clara a existência de mais de um nível possível de recepção ou 
interpretação da estrutura da obra intitulada Cidade do Sol, por onde aparecem as recomendações do autor para a política concreta da Itália renascentista, enquanto se explicitam visões ideais de cunho esotérico, de influência da astrologia.

Não seria coerente com o conjunto deste empreendimento, portanto, neste terceiro degrau de nossa pesquisa, tratar o texto de Rousseau de uma maneira demasiado plana e direta, apenas pela verificação das suas sugestões muito práticas de reforma para a constituição da Polônia, que o dirigente polonês, conde Wielhorski, desejava encaminhar.

A combinação típica de trabalho de Jean-Jacques, feita de desejo e razão, em nível ao mesmo tempo pessoal e universal, não indica uma divisão interna do seu pensamento; ao contrário, é uma característica que envolve e mantém unitária toda a sua obra. Em sua aparente fragmentação por causa dos gêneros literário e filosófico associados, e do estilo muito próprio, aos olhos dos especialistas o pensamento de Rousseau se manteve uno e coerente, apresentando uma firme unidade no que tange às idéias básicas que acompanham as variações de registro dos textos. Da meditação antropológica até a reflexão sobre os fundamentos do direito político, os estudiosos encontram as mesmas preocupações e os mesmos princípios que guiaram em toda a sua obra o pensamento político rousseauniano. ${ }^{1}$

Ainda assim, é problemático decidir o quanto de utopia se pode atribuir a um texto de Rousseau, sobretudo aos projetos, como o Projeto para a Córsega e as Considerações, que aqui relemos, e isso também porque não é simples estabelecer a relação do autor com a utopia. "Quimera", "devaneios", "sonhador" são termos que ocorrem em seus textos, mesmo em títulos de obras. O próprio pensador reconhece em múltiplas ocasiões seu gosto pelo "devaneio" ou pelas "ficções", gosto que reivindica e explica por seu temperamento e por sua experiência de vida, que o teria levado a buscar a fuga da realidade (Bachofen, 2002, p. 213).

Contudo, quando usa o termo "quimera", o escritor parece situar esses sonhos ou desejos como algo um tanto desviado do projeto concreto a ser aplicado à realidade por um governo em ação, no caso da obra aqui analisada. Não significa isso que as críticas e sugestões não sejam para serem tomadas a sério, ao contrário, pois "um pensamento político pode ser sério e utópico" e não sou a única a pensar que, talvez mesmo, um pensamento político só seja sério sob esta condição (Bachofen, 2002, p. 216)².

As Considerações começam com uma afirmação aparentemente clara, mas aberta para a dúvida, antes um voto que uma determinação certa: "Evitemos, se possível, lançar-nos, desde os primeiros passos, em projetos quiméricos...." ${ }^{3}$

Rousseau se interroga em seus textos sobre a questão da relação do real ao possível; nele é possível encontrar-se um julgamento crítico sobre as "quimeras" do pensamento político, como quando separa "a gente da Utopia" dos "filhos de Adão".

O pensador critica o excessivo otimismo antropológico na "gente da Utopia", entre a qual situa, por exemplo, os fisiocratas. Nesse juízo está contida a sua crítica da sociedade, que marca sua diferença ante o liberalismo e com relação à construção da ordem social, que os liberais julgam possível criar-se de modo espontâneo. Ao contrário do que pensavam ou esperavam os fisiocratas, como os liberais de seu tempo, para Rousseau a natureza é destruída pela ordem social que se forma espontaneamente, apoiada na propriedade privada e a sociedade de produção. ${ }^{5}$

\footnotetext{
1 Ver Bachofen (2002), capítulo "La politique chimérique ou les paradoxes de la liberté politique".

2 Lembremos aqui de novo o ensaio de Abensour (2000, pp. 31-103), que acompanhamos no artigo sobre Thomas More.

3 Obras completas III, capítulo V , p. 970, citado por Bachofen (2002, p. 217).

4 Em "Escritos sobre o abade Saint-Pierre", citado por Bachofen (2002, p. 220).

5 “Considérations...”, Flammarion, 1990, p. 182. Ver: Bachofen (2002, p. 221).
} 
Aparentemente o pensador não critica nos fisiocratas o caráter utópico de suas teorias; mais exatamente, critica-os por carregarem em suas teorias e expectativas um lote de quimeras sem reconhecê-lo, porque ignoram o "caráter de quimeras" de suas teses e esperanças (Bachofen, 2002).

A crítica de Rousseau, pois, não iria diretamente ao "quimérico" enquanto tal, ou seja, ao aspecto utópico do pensamento político, mas ao seu não reconhecimento enquanto "quimérico" dentro de particular pensamento político que se quer "realista". Haveria uma ilusão própria no realismo político, nas teorias que pensam dispensar sua parte de utopia, porque não reconhecem seu indispensável lado utópico e, assim, fazem-se ilusões sobre o real, tornando-se "quimeras". A crítica do caráter quimérico do projeto dos fisiocratas não se dirige ao que esse projeto tinha de propriamente utópico, no sentido de visar uma sociedade mais justa; a crítica de Jean-Jacques Rousseau visava seu caráter insuficientemente utópico, enquanto pretendiam poder dispensar a utopia e calcar sua teoria política unicamente sobre o real, pois o que lhe parecia ser uma quimera é o contrato social ditado pretensamente pela natureza. ${ }^{6}$

Além de um trabalho "técnico", entregue como contribuição à prática de um governo, as Considerações sobre o governo da Polônia podem ser consideradas entre as utopias no seu sentido mais positivo, como explorações do sonho possível que se contrapõe à realidade atual.

Penso legítimo supor que aquele ensaio rousseauniano em forma de projeto, embora escrito sob encomenda e com um propósito determinado e evidente, por assim dizer utilitário, portanto, de caráter aplicado, participe das características gerais comuns dos escritos do pensador Rousseau, que renegava a teoria descarnada e, mesmo em seus ensaios mais elevados acima do chão da vivência particular de Jean-Jacques, sua reflexão não se afastava de todo do impulso, da preferência pessoal, da inclinação, da liberdade, do tom confessional, da observação comprometida com o sentimento, mesmo a paixão, logo, permanecia muito unida com a imaginação.

Por isso, se não se pode considerar propriamente do domínio da utopia, por definição em busca da instauração do novo na história, aquele escrito em que o devaneio foi contido, porém, ainda assim o desejo comanda o discurso desenvolvido no plano do dever-ser e do imperativo, expressa o quão profundas e complexas se mantêm as relações entre a obrigação moral e o sonho para o pensador iluminista da democracia de Genebra.

Na utopia "retrógrada" de Jean-Jacques, ao mesmo tempo contraditória e simples, porque inspirada na natureza e no passado de simplicidade que antecede a civilização submetida à crítica, há lugar para o velho e para o novo da experiência humana, mas tanto este, como aquele serão frutos de muito esforço e trabalho, na política como na educação.

E como a civilização afastou o homem da natureza, portanto, da igualdade natural, é grande a tarefa que cabe para a educação. A educação coletiva será obra da organização política e, ao mesmo tempo, será a educação que encaminhará para a reconquista da sociedade igualitária, mais feliz e mais livre que esta, sofredora sob os grilhões do artifício e das farsas civilizatórias.

Para concluir, relembremos os três pontos antes destacados no projeto de reforma desenhado por por Rousseau para a Polônia, país então em busca de sua forma organizacional: primeiro, a questão da alma nacional e de sua formação no corpo de um povo; segundo, a crítica ao dinheiro, tido esse como meio e cerne do desenvolvimento, aspecto central do capitalismo da indústria ascendente; e, terceiro, o trabalho na administração pública, dentro do contexto dos estados-nações que se organizavam e afirmavam naquele período da época moderna.

6 Bachofen (2002), p. 222, referindo o "Manuscrito de Genebra I", p. 284. 
A confiança no trabalho da educação, e da educação escolar, para a criação de uma "alma" ou consciência nacional, historicamente tem sofrido vicissitudes diversas. Assim como a almejada "alma nacional", no decorrer destes dois séculos de revoluções e de guerras, em momentos privilegiados tem concorrido em benefício do bom convívio do povo e ao bom convívio entre os povos, contudo, em muitas ocasiões, infelizmente demasiado freqüentes, também foi usada na direção do conflito violento e da destruição. Por isso, a experiência recomenda e leva à conviç̧ão de que a "alma nacional" não pode ser a única pretensão da ordem educacional nem deveria ser a sua principal pretensão que se formem cidadãos de uma nacionalidade própria. Sobretudo hoje, num mundo ao mesmo tempo dilatado e reduzido pela intensidade dos transportes e das comunicações, em que a idéia de pátria chega a identificar-se com os limites do planeta, mais do que nunca o cosmopolitismo, a idéia de uma única humanidade e de direitos humanos comuns a todos os cidadãos do mundo, a todos os habitantes da Terra, coloca no centro da preocupação educativa antes a consciência de cidadania que a de nacionalidade.

Quanto à crítica ao dinheiro, esse me parece ser um traço bem típico do pensamento encontrado nas produções do gênero das utopias. Os utopistas modernos não sonharam nem compartilharam da ilusão liberal de que a boa sociedade pudesse edificar-se sobre as artes comerciais das finanças e a especulação. Essa atitude crítica com relação às conseqüências da "abstração" da economia - traço talvez passadista, saudosista, que apontava para épocas anteriores ao desenvolvimento moderno capitalista - parece aproximar Rousseau dos outros utopistas propriamente ditos, desde Thomas More até Charles Fourier.

Por outro lado, o trabalho na administração pública, como visto acima, foi concebido por Rousseau como obra conseqüente e desinteressada de homens com acentuado sentido público, tão distinto do interesse ligado ao modo especialista e profissional como também afastado do interesse egoista privado. Tal posição está bem distante da pretensão predominante em nosso tempo, quando as tarefas políticas se profissionalizam e é mesmo exigido pela opinião pública que sejam trabalhadas de modo profissional.

Por todos esses aspectos, mesmo pelo que destoam do lugar-comum da opinião predominante na atualidade, parece relevante promover a memória e revisão das idéias de Rousseau expressas no texto concebido como sugestões para o governo de um país em formação, embora o curso da história nos últimos dois séculos não nos permita ter a mesma percepção das relações econômicas, psicológicas, morais e políticas. E embora, justamente, soem como extemporâneos alguns de seus aspectos, o projeto moralizante das Considerações rousseaunianas, ao mesmo tempo independente da subserviência ao real e conservador, permanece utópico e provocativo da reflexão.

\section{Referências}

Abensour, M. (2000). L'utopie de Thomas More a Walter Benjamin. Paris: Sens \& Tonka.

Bachofen, B. (2002). La condition de la liberté. Rousseau, critique des raisons politiques. Paris: Payot.

Baczko, B. (1978). Lumières de l'Utopie. Paris: Payot.

Dent, N. J. H. (1996). Dicionário Rousseau. Rio de Janeiro: Zahar.

Marques, J. O. de A. (Org.) (2005). Verdades e mentiras. 30 ensaios em torno de Jean-Jacques Rousseau. Ijuí: Editora Unijui.

Petitfils, J.-C. (1977). Os socialismos utópicos. São Paulo: Círculo do Livro. 
Rousseau, J.-J. (1973). Do Contrato Social. Ensaio sobre a origem das línguas. Discurso sobre a origem e os fundamentos da desigualdade entre os homens. Discurso sobre as ciências e as artes (Coleção Os Pensadores, vol. 24). São Paulo: Abril.

Rousseau, J.-J. (1990). Sur l'économie politique. Considérations sur le gouvernement de Pologne. Projet pour la Corse. Paris: Flammarion.

Rousseau, J.-J. (1998). Les Rêveries du promeneur solitaire. Paris: Pocket.

Rousseau, J.-J. (1999). Emílio ou da educação. São Paulo: Martins Fontes.

Rousseau, J.-J. (1999). De l'inégalité parmi les hommes. Paris: Libio.

\section{Endereço para correspondência}

suzanaalb@viavale.com.br

Recebido em: 30/07/2005

Aprovado em: 18/07/2006 


\section{Cadernos de Psicologia Social do Trabalho}

\section{Pedido de assinatura e de exemplares avulsos}

Para fazer uma assinatura ou solicitar qualquer exemplar avulso, envie-nos a ficha abaixo preenchida e cheque nominal ao Instituto de Psicologia - USP. Por gentileza, escreva ou telefone para saber os valores atuais de cada exemplar ou da assinatura.

Centro de Psicologia Aplicada ao Trabalho

Av. Prof. Mello Moraes, 1721

Bloco D, sala 163

Cidade Universitária, São Paulo/ SP

05508-030

Endereço eletrônico: cpat@usp.br

\begin{tabular}{|l|l|c|c|}
\hline Quantidade & \multicolumn{1}{|c|}{ Pedido } & \multicolumn{1}{|c|}{ Valor $^{*}$} & \multicolumn{1}{|c|}{ Total } \\
\hline & volume 1 & esgotado & esgotado \\
\hline & volume 2 & & \\
\hline & volume 3/4 & & \\
\hline & volume 5 & & \\
\hline & volume 6 & & \\
\hline & $\begin{array}{l}\text { volume 7 } \\
\text { volume 8 }\end{array}$ & & \\
\hline & volume 9, número 1 & Total: R\$ \\
\hline & assinatura por dois anos (quatro exemplares) & & \\
\hline & & & \\
\hline
\end{tabular}

" Por favor, consultem-nos a respeito dos valores antes de fazer seus pedidos.

\begin{tabular}{|c|c|c|}
\hline Nome: & & \\
\hline Endereço: & & \\
\hline & & CEP: \\
\hline Cidade: & & Estado: \\
\hline Telefone: ( ) & E-mail: & \\
\hline Data: / / & Assinatura: & \\
\hline
\end{tabular}

